Borislav Malinović1, Tijana Djuričić ${ }^{1 *}$, Duško Zorić ${ }^{2}$

${ }^{1}$ University of Banja Luka, Faculty of Technology, Banja Luka, $R$. Bosnia and Herzegovina, ${ }^{2}$ EFT Mine and Thermal Power Plant Stanari Ltd., Stanari, R. Bosnia and Herzegovina
Scientific paper

ISSN 0351-9465, E-ISSN 2466-2585

UDC: $669.14 .018 .8: 665.7 .038 .5$

doi: $10.5937 /$ zasmat2002133M

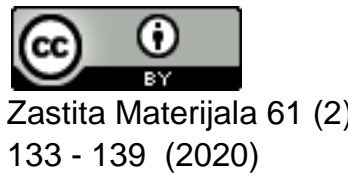

\title{
Corrosion behaviour of stainless steel EN 1.4301 in acid media in presence of PBTCA inhibitor
}

\begin{abstract}
In this study, corrosion behaviour of stainless steel in $0.5 \mathrm{M}$ and $1 \mathrm{M}$ hydrochloric acid was examined. Also, commercial corrosion inhibitor which contain 2-phosphonobutane-1,2,4tricarboxylic acid (PBTCA) is examined as potential inhibitor for stainless steel EN 1.4301 in $0.5 \mathrm{M}$ hydrochloric acid. For experimental research it was used DC-technique (Tafel extrapolation, linear polarization method and potentiodynamic polarization). The obtained results show that the inhibitor is effective in mentioned acid environment and the protection efficiency depends primarily on the concentration of the inhibitor. Based on the obtained results this inhibitor has moderate inhibition efficiency, since the highest efficacy was achieved $E_{i}=55.7 \%$. According to the corrosion mechanism the inhibitor is behaved as a mixed inhibitor.
\end{abstract}

Keywords: Corrosion rate, protection efficiency, DC-technique.

\section{INTRODUCTION}

In modern industry corrosion is a serious problem as from the technical, also from ecological and economical aspects. There are several methods of corrosion protection. These methods can be classified as changing electrode potential of the metal surface or changing the nature of the metal. Cathodic and anodic protection are two methods of controlling corrosion by changing the electrode potential. Very often, material selection is not possible due to the requirement to maintain another desirable characteristic, or is economically unprofitable. In such cases, the use of corrosion inhibitors then becomes a possible way of controlling corrosion [1].

Organic compounds, predominantly, those with $\mathrm{O}, \mathrm{N}, \mathrm{S}, \mathrm{P}$ and/or $\pi$ electrons in their molecular structure have received considerable attention as metals corrosion inhibitor. It is believed that organic compounds get adsorb onto metal surface through their active center (heteroatom or $\pi$-bond) and form a protective layer that prevent the corrosive agents

\footnotetext{
${ }^{*}$ Corresponding author: Tijana Djuričić

E-mail: tijana.malinovic@tf.unibl.org

Paper received: 18. 02. 2020.

Paper accepted: 29. 03. 2020.

Paper is available on the website:

www.idk.org.rs/journal
}

in the aggressive environment from gaining access into the metal surface. Compared to the inorganic metal corrosion inhibitors, the organic inhibitors are less toxic to both human and the environment making discontinuation not to be the best option [2].

From the mid-1970s to 2000s, phosphonates were developed and extensively used as scale and corrosion inhibitors in a variety of fields including circulating cooling systems in power plants, industrial equipment cleaning, industrial water treatment, corrosion inhibitors in concrete, coating, rubber blends, acids cleaners and anti-freeze coolants. Some of phosphonates have been used with metal cations because the synergistic effect between inhibitor gives the more inhibition efficiency [3-5].

Stainless steels are known for their good corrosion resistance in many corrosive environments, but in the presence of chloride ions are susceptible to localized corrosion. For that reason stainless steel are often additionally protected (coatings, corrosion inhibitors) when used in chloride environment [6].

The corrosion behavior of stainless steel in the presence of chloride has been the subject of many researches. The behavior of AISI 304 steel (EN 1.4301) in different corrosive media, such as $\mathrm{H}_{2} \mathrm{SO}_{4}, \mathrm{HCl}[6,7], \mathrm{NaCl}[8,9]$, at different $\mathrm{pH}$ values 
[10], was investigated. The tests were performed by different methods (AC -, DC - techniques, weight loss method...), and it was found that the mentioned steel has high corrosion resistance, but under certain conditions the passive layer is damaged and corrosion occurs, and in the presence of chloride ions pitting corrosion almost always occurs.

Also in many researchs it was examined effect of PBCTA as corrosion and scale inhibitor [11-14]. Tests have shown mentioned inhibitor is effective as a corrosion and scale inhibitor for a different materials, but tests have generally been performed in the alkaline medium. The inhibition rate of PBTCA increase with increasing $\mathrm{pH}$, which indicate that the protective film was more favourable to the reagent formation in the alkaline environment. This is likely because the concentration of hydrogen ions in water decreases with the increasing $\mathrm{pH}$, and thus, the depolarization of hydrogen ions in the process of metal corrosion is inhibited at high $\mathrm{pH}$ [15].

The aim of this paper was examine the behavior of EN 1.4301 stainless steel at different concentrations of hydrochloric acid $(0.5 \mathrm{M}$ and $1 \mathrm{M})$, and also the effect of a comercial industrial corrosion inhibitor (which contain PBTCA) on corrosion rate of EN 1.4301 stainless steel in acid media.

\section{EXPERIMENTAL}

For the experimental purpose stainless steel EN 1.4301 (AISI 304; max. 0.07\% C, $18.1 \% \mathrm{Cr}$, $8.2 \% \mathrm{Ni}$ ) was used. The mentioned material was used as a working electrode, which was prepared manually by cutting $6 \mathrm{~mm}$ radius rods and inserting them into an inert teflon carrier. The working surface of the electrode was $0.28 \mathrm{~cm}^{2}$. As the reference electrode it was used $\mathrm{Ag} / \mathrm{AgCl}$ (3.5M $\mathrm{KCl}, E=0.205 \mathrm{~V}$ ) and the counter electrode was platinum.

Before each measurement, the working electrode was polished with sandpaper $(\mathrm{SiC})$ of different gradations $(800,1200,1500)$ and then polished with alumina $\left(\mathrm{Al}_{2} \mathrm{O}_{3}\right)$. After polishing, the electrode was cleaned with detergent and water, cleaned with ultrasonic in destiled water, degreased in acetone, washed with distilled water and dried.

To prepare the corrosive medium $(0.5 \mathrm{M}$ and $1 \mathrm{M} \mathrm{HCl}), 35 \%$ hydrochloric acid was used (Lachner, Czech Republic) and 99.9\% acetone from the same manufacturer was used to degrease the working electrode. All the listed chemicals are of p.a. purity and all tests were performed at ambient temperature.

The working electrode was 12 hours in the test solution before the measurement. Electrochemical testing and determination of corrosion parameters $\left(E_{\text {corr }}, R_{p}, I_{\text {corr }}, \pi\right)$ were performed on a Princeton Applied Research potentiostat (PAR model 273A) with PowerSuite software package.

The electrochemical properties of EN 1.4301 stainless steel in $0.5 \mathrm{M}$ and $1 \mathrm{M} \mathrm{HCl}$ solution were tested by potentiodynamic polarization method. The linear polarization method and the Tafel extrapolation were used to determine corrosion parameters and test the efficiency of a commercial corrosion inhibitor in $0.5 \mathrm{M} \mathrm{HCl}$.

The commercial industrial corrosion inhibitor used in this work is HEMOD MS 1E. According to the chemical composition specified in its MSDS, inhibitor HEMOD MS 1E consists of sodium hydroxide (10-15\%) and 2-phosphonobutane-1,2,4tricarboxylic acid (20-25\%) [16].

\section{RESULTS AND DISCUSION}

The first part of the study consists of testing the behavior of stainless steel in an aggressive corrosive environment $(0.5 \mathrm{M}$ and $1 \mathrm{M} \mathrm{HCl})$. Corrosion behavior at different acid concentrations was monitored and corrosion parameters were determined $\left(E_{c o r r}, R_{p}, I_{c o r r}, \pi\right)$. In the second part of the study, the efficiency of the corrosion inhibitor was tested, when it was added to the corrosive medium $(0.5 \mathrm{M} \mathrm{HCl})$. It was determined at which concentration inhibit corrosion processes on mentioned material.

The efficiency of the inhibitor, $E_{i}(\%)$, was calculated based on following equation:

$$
E_{i}=\frac{\pi-\pi^{*}}{\pi} \cdot 100
$$

where:

$\pi$ - corrosion rate in solution without corrosion inhibitor $\left(\mathrm{mm}\right.$ year $\left.{ }^{-1}\right)$

$\pi$ '- corrosion rate in solution with corrosion inhibitor $\left(\mathrm{mm}\right.$ year $\left.{ }^{-1}\right)$

After the corrosion potential is established, the working electrode is polarized. The electrode was first cathodic polarized up to $-0.25 \mathrm{~V}$ with respect to $E_{\text {corr }}$ then anodic polarized up to $1.3 \mathrm{~V}$ with respect to $E_{\text {corr, }}$ with a potential change rate of $0.166 \mathrm{mV} \mathrm{s}^{-1}$.

Based on the potentiodynamic curves (Figure 1 ), it can be concluded that there is almost no difference in the behavior of the steel in $0.5 \mathrm{M}$ (green line) and $1 \mathrm{M} \mathrm{HCl}$ (blue line) in around of $E_{\text {corr. }}$ The difference is only noticeable above primary passivation potential $\left(E_{p p}\right)$, respectively, in $0.5 \mathrm{M} \mathrm{HCl}, E_{p p}$ is established earlier (-0.2 V), which means that the steel passivates faster in $0.5 \mathrm{M} \mathrm{HCl}$ compared to $1 \mathrm{M} \mathrm{HCl}(-0.15 \mathrm{~V})$. 


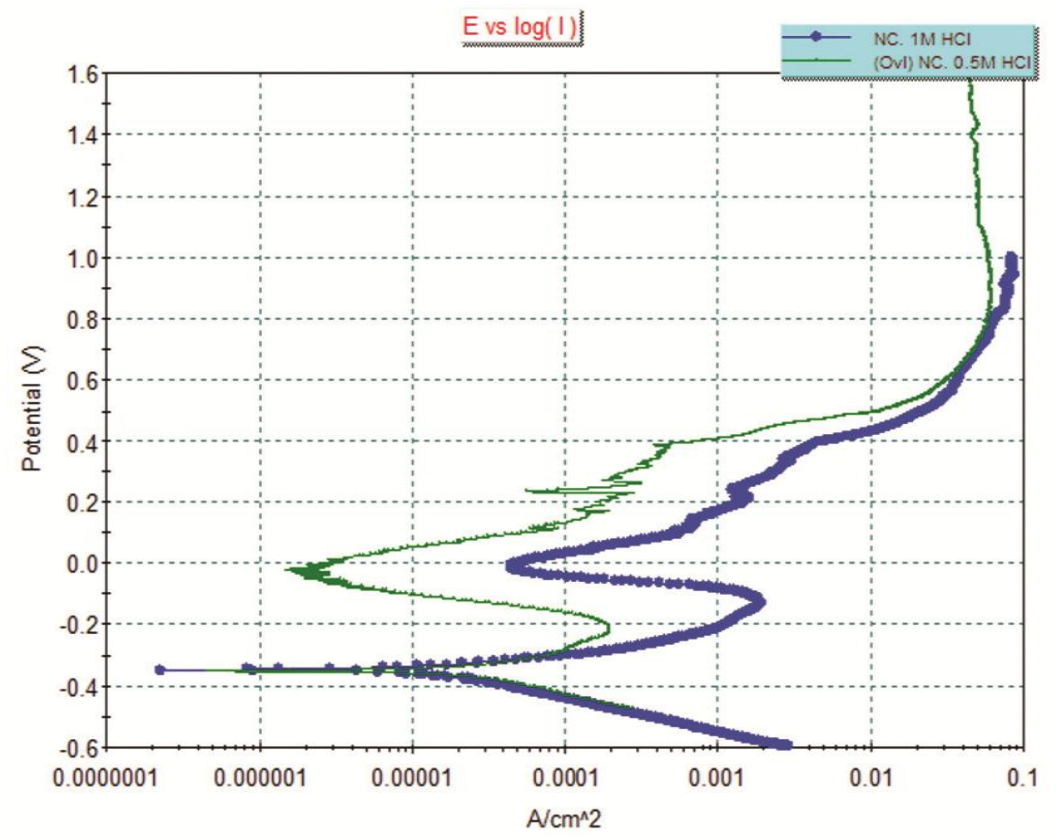

Figure 1. Potentiodynamic polarization curves of EN 1.4301 in $0.5 \mathrm{M}$ and $1 \mathrm{M} \mathrm{HCl}$

Slika 1. Krive potenciodinamičke polarizacije nerđajućeg čelika EN 1.4301 u $0.5 \mathrm{M} \mathrm{i} 1 \mathrm{M} \mathrm{HCl}$

In order to determine the corrosion parameters of the steel in the tested acidic environment, linear polarization (measurement of polarization resistance) in the range $\pm 20 \mathrm{mV}$ (with respect to $\left.E_{c o r r}\right)$ was performed, with the rate of potential change of $0.166 \mathrm{mV} \mathrm{s}^{-1}$.

Table 1 shows the values of corrosion parameters determined by this method, and Figure 2 shows the slope obtained by recording the resulting current as a function of the applied potential. A higher value of polarization resistance in $0.5 \mathrm{M} \mathrm{HCl}$, as well as a lower value of corrosion current, indicates a higher stability of steel in $0.5 \mathrm{M}$ $\mathrm{HCl}$ (blue line), compared to its stability in $1 \mathrm{M} \mathrm{HCl}$ (green line).

The obtained values of the current density and polarization resistance in the research of Curkovic et al. were $j_{\text {corr }}=20.52 \mu \mathrm{A} \mathrm{cm}^{-2}$ and $R_{p}=1115 \Omega \mathrm{cm}^{2}$ for the same material, in $0.5 \mathrm{M} \mathrm{HCl} \mathrm{[6].} \mathrm{The}$ obtained value of current density was $20.4 \mu \mathrm{A} \mathrm{cm}^{-2}$, which is in accordance with the previous research, while the value of polarization resistance is different.

Table 1. Corrosion parameters determined by linear polarization method

Tabela 1. Korozijski parametri određeni metodom linearne polarizacije

\begin{tabular}{|c|c|c|c|c|}
\hline Medium & $E_{\text {corr }}(\mathrm{V})$ & $R_{p}(\Omega)$ & $I_{\text {corr }}(\mu \mathrm{A})$ & $\pi(\mathrm{mm}$ year \\
\end{tabular}

In addition to determining the corrosion parameters by linear polarization method, the same parameters $\left(I_{\text {corr, }}, \pi\right)$ were determined by Tafel extrapolation. The diagram from Figure 3 . shows that corrosion behavior of the steel in $0.5 \mathrm{M}$ (blue line) and $1 \mathrm{M} \mathrm{HCl}$ (green line) is similar, but the obtained values of $I_{\text {corr }}$ and $\pi$ indicate greater stability of the steel in $1 \mathrm{M} \mathrm{HCl}$. The lower values of $I_{\text {corr }}$ and $\pi$ in $1 \mathrm{M} \mathrm{HCl}$ may be due to the lower value of Tafel constant $\left(\beta_{k}\right)$ compared to the value in $0.5 \mathrm{M} \mathrm{HCl}$.
In the further study $0.5 \mathrm{M} \mathrm{HCl}$ was used as corrosive medium and different concentrations of inhibitor were added. Table 3 shows the values of corrosion parameters obtained by the linear polarization method at different concentrations of HEMOD MS 1E inhibitor. A double increase in polarization resistance and a decrease in current density and corrosion rate were achieved at an inhibitor concentration of $0.15 \mathrm{~mL} / \mathrm{L}$. 


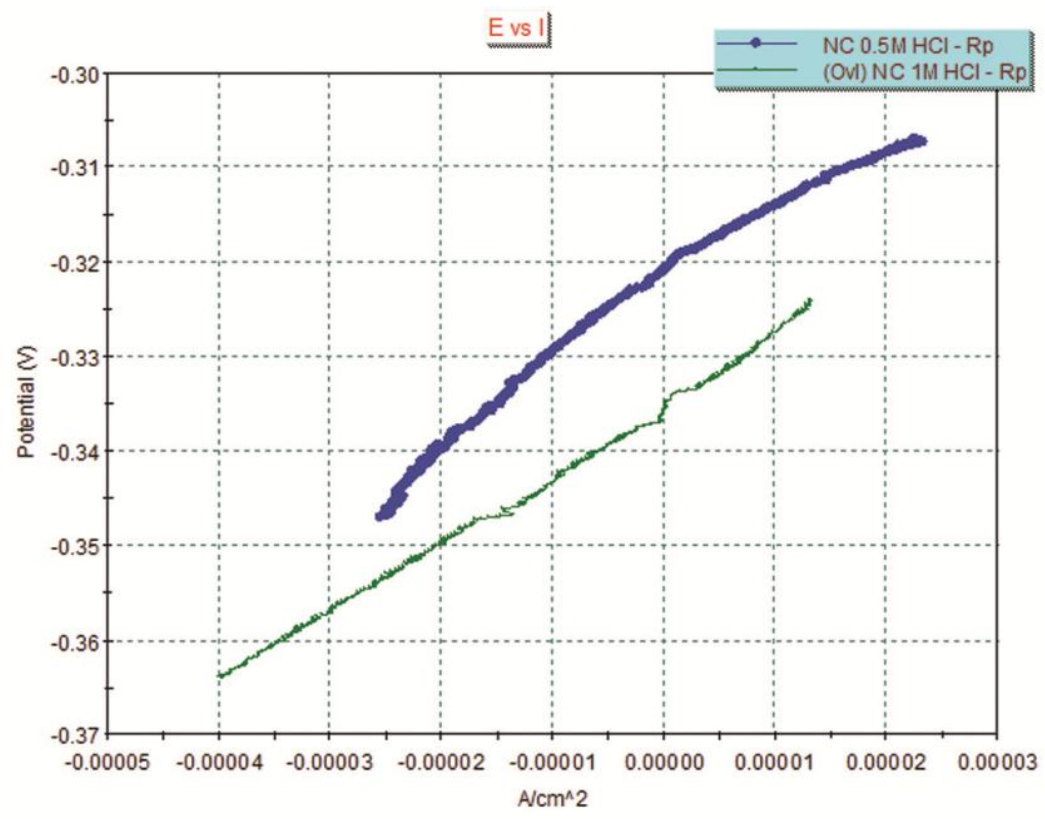

Figure 2. Polarization curve of EN 1.4301 in $0.5 \mathrm{M}$ and $1 \mathrm{M} \mathrm{HCl}$

Slika 2. Polarizacijske krive nerđajućeg čelika EN 1.4301 u $0.5 \mathrm{M} \mathrm{i} 1 \mathrm{M} \mathrm{HCl}$

Table 2. Corrosion parameters determined by Tafel extrapolation method

Tabela 2. Korozijski parametri određeni metodom Tafelove ekstrapolacije

\begin{tabular}{|c|c|c|c|c|c|c|}
\hline Medium & $E_{\text {corr }}(\mathrm{V})$ & $E_{p p}(\mathrm{~V})$ & $\beta_{k}(\mathrm{mV} /$ dek $)$ & $\beta_{a}(\mathrm{mV} /$ dek $)$ & $I_{\text {corr }}(\mu \mathrm{A})$ & $\pi\left(\mathrm{mm}_{\text {year }}{ }^{-1}\right)$ \\
\hline $0.5 \mathrm{M} \mathrm{HCl}$ & -0.326 & -0.151 & 122 & 60 & 18.3 & 0.7213 \\
\hline $1 \mathrm{M} \mathrm{HCl}$ & -0.347 & -0.160 & 99 & 58.5 & 10.7 & 0.3733 \\
\hline
\end{tabular}

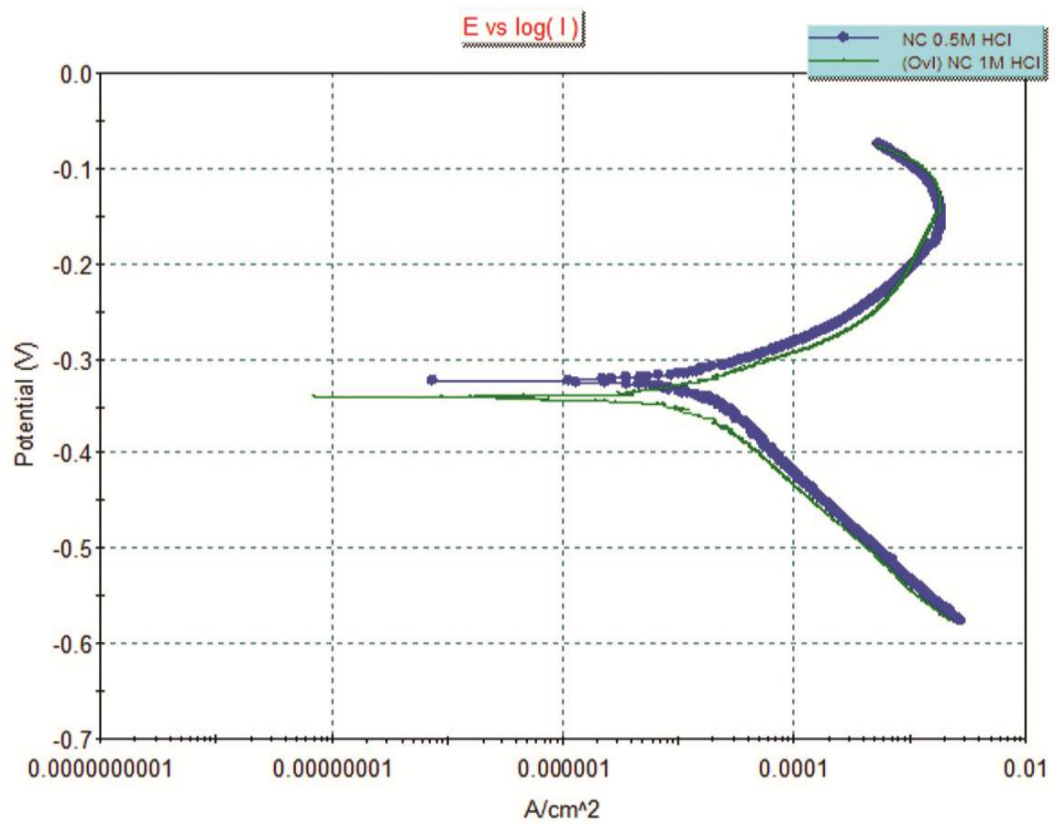

Figure 3. Tafel extrapolation of EN 1.4301 in $0.5 \mathrm{M}$ and $1 \mathrm{M} \mathrm{HCl}$

Slika 3. Tafelova ekstrapolacija nerđajućeg čelika EN 1.4301 u $0.5 \mathrm{M} \mathrm{i} 1 \mathrm{M} \mathrm{HCl}$ 
Table 3. Corrosion parameters determined by linear polarization method

Tabela 3. Korozijski parametri određeni metodom linearne polarizacije

\begin{tabular}{|c|c|c|c|c|}
\hline Medium & $E_{\text {corr }}(\mathrm{V})$ & $R_{p}(\Omega)$ & $I_{\text {corr }}(\mu \mathrm{A})$ & $\pi\left(\mathrm{mm} \mathrm{year}^{-1}\right)$ \\
\hline $0.5 \mathrm{M} \mathrm{HCl}$ & -0.332 & 851.6 & 20.4 & 0.7172 \\
\hline $0.5 \mathrm{M} \mathrm{HCl}+0.07 \mathrm{~mL} / \mathrm{L}$ HEMOD & -0.308 & 1127.5 & 17.1 & 0.6302 \\
\hline $0.5 \mathrm{M} \mathrm{HCl}+0.15 \mathrm{~mL} / \mathrm{L} \mathrm{HEMOD}$ & -0.284 & 1731.8 & 8.6 & 0.3171 \\
\hline $0.5 \mathrm{M} \mathrm{HCl}+0.30 \mathrm{~mL} / \mathrm{L} \mathrm{HEMOD}$ & -0.316 & 375.0 & 48.2 & 1.7700 \\
\hline
\end{tabular}

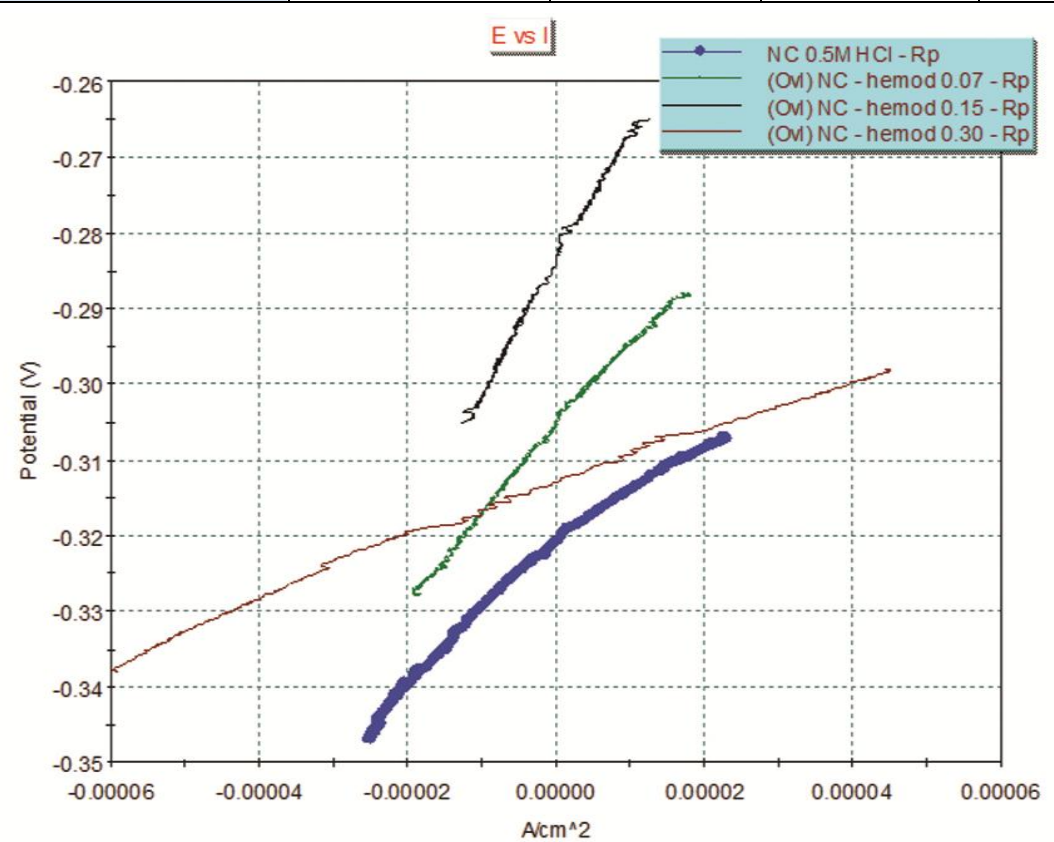

Figure 4. Polarization curves of EN 1.4301 in the presence of different concentrations of HEMOD MS 1E

Slika 4. Polarizacijske krive nerđajućeg čelika EN 1.4301 u prisustvu različitih koncentracija inhibitora HEMOD MS $1 E$

The diagram in Figure 5 shows the efficiencies achieved at different concentrations of inhibitors. Increasing the inhibitor concentration from 0.07 to $0.15 \mathrm{~mL} / \mathrm{L}$ resulted in a decrease in the corrosion rate, with the highest efficiency achieved $\left(E_{i}=\right.$ $55.7 \%)$. A further increase in concentration results in a sharp increase in the corrosion rate.

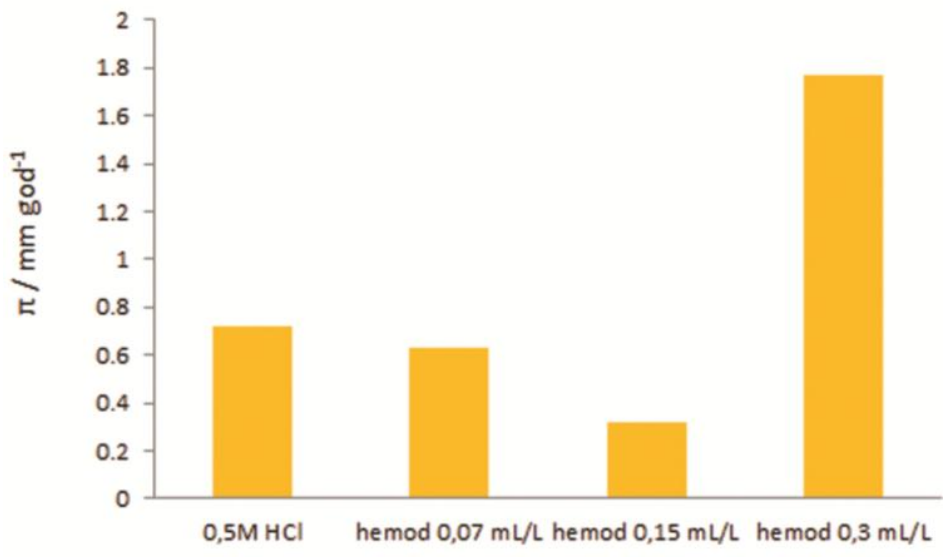

Figure 5. Efficiency of HEMOD MS $1 E$ inhibitors calculated by linear polarization method

Slika 5. Efikasnost inhibitora HEMOD MS 1 E računato metodom linearne polarizacije 
Based on the values of corrosion parameters determined by Tafel extrapolation (Table 4), it was also confirmed that at a concentration of inhibitors of $0.15 \mathrm{~mL} / \mathrm{L}$, the best results were obtained in protecting of corrosion.

Table 4. Corrosion parameters determined by Tafel extrapolation method

Tabela 4. Korozijski parametri određeni metodom Tafelove ekstrapolacije

\begin{tabular}{|c|c|c|c|c|c|c|}
\hline Medium & $E_{\text {corr }}(\mathrm{V})$ & $E_{p p}(\mathrm{~V})$ & $\beta_{k}(\mathrm{mV} /$ dek $)$ & $\beta_{a}(\mathrm{mV} /$ dek $)$ & $I_{\text {corr }}(\mu \mathrm{A})$ & $\pi\left(\mathrm{mm}_{\mathrm{m} \text { year }}{ }^{-1}\right)$ \\
\hline $0.5 \mathrm{M} \mathrm{HCl}$ & -0.326 & -0.151 & 122 & 60 & 18.3 & 0.7213 \\
\hline $0.5 \mathrm{M} \mathrm{HCl}+0.07 \mathrm{~mL} / \mathrm{L} \mathrm{HEMOD}$ & -0.308 & -0.217 & 130.6 & 67.5 & 17.5 & 0.6426 \\
\hline $0.5 \mathrm{M} \mathrm{HCl}+0.15 \mathrm{~mL} / \mathrm{L} \mathrm{HEMOD}$ & -0.284 & -0.218 & 105.6 & 51 & 7.3 & 0.2669 \\
\hline $0.5 \mathrm{M} \mathrm{HCl}+0.30 \mathrm{~mL} / \mathrm{L} \mathrm{HEMOD}$ & -0.316 & -0.129 & 122.3 & 63 & 18.2 & 0.6883 \\
\hline
\end{tabular}

From Figure 6 it is clearly observed that the value of $E_{\text {corr }}$ has slightly changed by the addition of inhibitor. The cathodic parts of the curve are parallel, which means that the HEMOD MS $1 \mathrm{E}$ inhibitor does not change the cathodic reaction mechanism, but significantly affects the anodic reaction mechanism in the $E_{p p}$ region. At a concentration of inhibitor of 0.07 (green line) and $0.15 \mathrm{~mL} / \mathrm{L}$ (black line), the passive layer forms much faster, while at a concentration of $0.30 \mathrm{~mL} / \mathrm{L}$ (red line), $E_{p p}$ is established later than in the solution without inhibitor. According to inhibitors action mechanism, this is a mixed inhibitor with a greater influence on the anodic reaction.

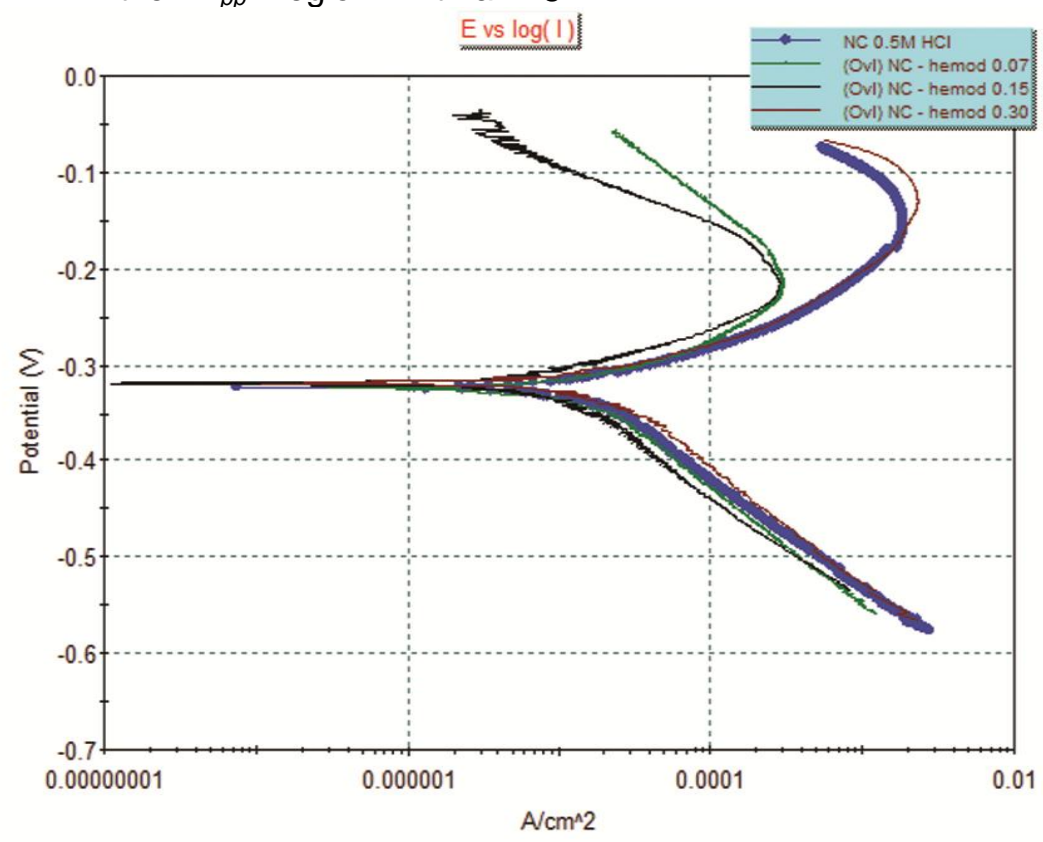

Figure 6. Tafel extrapolation of EN 1.4301 in the presence of different concentrations of HEMOD MS 1E

Slika 6. Tafelova ekstrapolacija nerđajućeg čelika EN 1.4301 u prisustvu različitih koncentracija inhibitora HEMOD MS $1 E$

\section{CONCLUSION}

Based on the results obtained by electrochemical methods of testing the corrosion process on EN 1.4301 stainless steel, as well as testing the effectiveness of a commercial corrosion inhibitor (HEMOD MS 1E), it can be concluded that stainless steel shows higher stability in $0.5 \mathrm{M} \mathrm{HCl}$ compared to $1 \mathrm{M} \mathrm{HCl}$. Tested inhibitor is effective in protecting stainless steel in $0.5 \mathrm{M} \mathrm{HCl}$, and the degree of protection depends on the inhibitor concentration. The highest efficiency was achieved with the HEMOD MS 1E inhibitor at a concentration of $0.15 \mathrm{~mL} / \mathrm{L}$. According to the corrosion mechanism, it acts as mixed inhibitors.

\section{Acknowledgements}

This work was supported in part by the Ministry of Scientific and Technological Development, Higher Education and Information Society Government of Republic of Srpska under Project 19/6-020/961-79/18. 


\section{REFERENCES}

[1] E.McCafferty (2009) Introduction to corrosion science (textbook). Washington: Springer New York Dordrecht Heidelberg London.

[2] S.A.Umoren, M.M.Solomon (2017) Synergistic corrosion inhibition effect of metal cations and mixtures of organic compounds: A Review, Journa of Environmental Chemical Engineering, 5(1), 246273.

[3] R.Liang, J.Li, M.Liu, Z.Y.Huang (2018) Influence of inhibitors on the adhesion of SRB to the stainless steel in circulating cooling water, Colloids and Surfaces B: Biointerfaces, 172, 1-9.

[4] R.Touira, N.Dkhirechea, M.Ebn Touhamia, M. Sfaira, O.Senhajic, J.J.Robind, B.Boutevind, M. Cherkaouia (2010) Study of phosphonate addition and hydrodynamic conditions on ordinary steel corrosion inhibition in simulated cooling water, Materials Chemistry and Physics, 122(1), 1-9.

[5] B.B.Karthik, P.Selvakumar, C.Thangavelu (2012) Phosphonic Acids used as Corrosion Inhibitors - A Review, Asian Journal of Chemistry, 24(8), 33033308.

[6] L.Ćurković, H.Otmačić - Ćurković, S.Salopek, M. Majić Renjo, S.Šegota (2013) Enhancement of corrosion protection of AISI 304 stainless steel by nanostructured sol-gel $\mathrm{TiO} 2$ films, Corrosion Science, 55, 176-184.

[7] R.T.Loto (2013) Pitting corrosion evaluation of austenitic stainless steel type 304 in acide chloride media, Journal of Materials and Environmental Science, 4(4), 448-459.

[8] A.Rustandi, B.Ramadhan, A.Fadhil, S. Setiawan (2016) Corrosion behavior of austenitic stainless steel $304 \mathrm{~L}$ and $316 \mathrm{~L}$ in aqueous sodium chloride solution by using electrochemical impedance spectroscopy, International Journal of Mechanical And Production Engineering, 4(12), 70-74.
[9] A.Rustandi, M.Nuradityatama, F.Rendi, S.Setiawan (2017) The use of cyclic polarization method for corrosion resistance evaluation of austenitic stainless steel 304L and 316L in aqueous sodium chloride solution, International Journal of Mechanical Engineering and Robotics Research, 21, 512-518.

[10] M.S.Sanusi, S.R.Shamsudin, A.Rahmat, R.Wardan (2018) Electrochemical corrosion behaiours of AISI 304 stainless steel in 3,5\% nacl solution at different $\mathrm{pH}$, AIP conference proceedings 2030. AIP Publishing.

[11] Y.Wang, H.Chen, Z.Zhang, H.Huang, B.Liu, K.Ding (2019) Synthesis and characterization of PBTCAmodified hyperbranched polyether corrosion and scale inhibitors, Journal of Applied Polymer Science, 136(38), 1-10.

[12] Kh.Rahmani, R.Jadidian, S.Haghtalabb (2016) Evaluation of inhibitors and biocides on the corrosion, scaling and biofouling control of carbon steel and copper-nickel alloys in a power plant cooling water system, Desalination, 393, 174-185.

[13] H.Huang, Q.Yao, B.Liu, N.Shan, H.Chen (2017) Synthesis and characterization of scale and corrosion inhibitors with hyper-branched Structure and its mechanism, New Yournal of Chemistry, 41(20), 1-29.

[14] B.N.Malinovi, D.Zoric, T.Djuricic (2019) 21. YUCORR, Tara, Serbia, proceedings, p. 233-241.

[15] L.Liu, T-T.Cao, Q-W.Zhang, C-W.Cui (2018) Organic Phosphorus Compounds as Inhibitors of Corrosion of Carbon Steel in Circulating Cooling Water: Weight Loss Method and Thermodynamic and Quantum Chemical Studies, Advances in Materials Science and Engineering, (article ID: 1653484), 1-10.

[16] Patenting d.o.o. Beograd (2013) Bezbedonosni list HEMOD MS - 1E. Beograd.

\title{
IZVOD
}

\section{KOROZIONO PONAŠANJE NERĐAJUĆEG ČELIKA EN 1.4301 U KISELOJ SREDINI U PRISUSTVU PBTCA INHIBITORA}

U ovom radu ispitano je koroziono ponašanje nerđajućeg čelika u 0,5M i 1 M hlorovodičnoj kiselini. Takođe, ispitan je komercijalni inhibitor korozije koji sadrži 2-fosfonobutan-1,2,4-trikarboksilnu kiselinu (PBTCA) kao potencijalni inhibitor korozije nerđajućeg čelika EN 1.4301 u 0,5M hlorovodičnoj kiselini. Za eksperimentalna istraživanja korištena je DC tehnika (Tafelova ekstrapolacija, metoda linearne polarizacije i potenciodinamička polarizacija). Dobijeni rezultati pokazuju da je inhibitor efikasan u navedenom kiselom mediju, a efikasnost zaštite prvenstveno zavisi od koncentracije inhibitora. Na osnovu dobijenih rezultata, inhibitor pokazuje inhibicijsku efikasnost, budući da najveća postignuta efikasnost iznosi $E_{i}=55,7 \%$. Prema mehanizmu djelovanja inhibitor se ponaša kao mješoviti inhibitor.

Ključne riječi: brzina korozije, efikasnost zaštite, DC-tehnika.

\author{
Naučni rad \\ Rad primljen: 18. 02. 2020. \\ Rad prihvaćen: 29. 03. 2020. \\ Rad je dostupan na sajtu: www.idk.org.rs/casopis
}

(c) 2020 Authors. Published by Engineering Society for Corrosion. This article is an open access article distributed under the terms and conditions of the Creative Commons Attribution 4.0 International license (https://creativecommons.org/licenses/by/4.0/) 